\title{
DESIGN AND MULTIMEDIA LEARNING PRINCIPLES ON MOOC INDONESIAX
}

\author{
Andreas Rio Adriyanto*, Imam Santosa, Achmad Syarief, Irfansyah \\ Institut Teknologi Bandung, Indonesia \\ *e-mail: imamz@,fsrd.itb.ac.id
}

\begin{abstract}
The "Kampus Merdeka" or "Freedom Campus" policy from the Indonesian Ministry of Education gives students the freedom to participate in learning activities outside their study program. Learning resources can be obtained from online-based learning. One online learning resource is Massive Online Open Course (MOOC), which has gained massive participation. Good quality learning materials can help students construct their knowledge. Indonesian MOOC providers have developed their learning materials, but they are still not optimal in quality. This study aims to analyze the implementation of design and multimedia principles on Indonesian MOOC's learning materials. The research used a quantitative strategy with the data collection method of visual observation of the IndonesiaX materials compared to those of edX, Udemy, and Coursera materials. Data analysis was based on the visual analysis of 9 design principles and 12 multimedia learning principles. In this research, the findings reveal that the design consistency and icon representation principles are yet to have an optimal grade. The same conditions are also found in implementing the multimedia principles of coherence, redundancy, and modality. The findings in this study are expected to be a consideration for MOOC providers in designing better online learning materials.
\end{abstract}

\section{Keywords: MOOC, IndonesiaX, multimedia learning, the design principle.}

\section{PRINSIP DESAIN DAN PEMBELAJARAN MULTIMEDIA PADA MOOC INDONESIAX}

\begin{abstract}
Abstrak: Kebijakan "Kampus Merdeka" dari Kemendikbud Indonesia adalah memberikan kebebasan mahasiswa untuk dapat mengikuti kegiatan pembelajaran di luar dari program studi. Sumber pembelajaran tersebut dapat diperoleh dari pembelajaran berbasis daring. Salah satu sumber pembelajaran daring adalah Massive Online Open Course (MOOC) yang terbuka dengan partisipasi besar. Kualitas materi ajar yang baik dapat membantu siswa dalam mengonstruksi pengetahuan. Penyedia MOOC di Indonesia telah mengembangkan materi ajarnya, namun masih belum optimal dalam kualitas materi. Tujuan penelitian ini adalah menganalisis penerapan prinsip desain dan multimedia pada materi ajar penyedia MOOC Indonesia. Penelitian menggunakan strategi kuantitatif dengan metode pengumpulan data lewat pengamatan visual pada materi IndonesiaX dengan perbandingan pada materi edX, Udemy dan Coursera. Analisis data menggunakan analisis visual dari 9 prinsip desain dan 12 prinsip pembelajaran multimedia. Temuan dalam penelitian ini adalah pada prinsip desain konsistensi, representasi ikon masih memiliki nilai yang tidak optimal, kondisi yang sama juga ditemui pada penerapan prinsip multimedia koherensi, redundansi dan modalitas. Temuan dalam penelitian ini diharapkan dapat menjadi pertimbangan bagi penyelenggara MOOC dalam merancang materi ajar daring yang lebih baik.
\end{abstract}

Kata Kunci: MOOC, IndonesiaX, pembelajaran multimedia, prinsip desain.

\section{INTRODUCTION}

The "Kampus Merdeka" policy from the Indonesian Ministry of Education and Culture gives students the right to take courses outside the study program. It aims to encourage students to get new experiences outside the campus. The labor skills required by the market are sometimes different from the curriculum. Market speed anticipates technology and information that creates much new knowledge that has not been prepared by universities. The university curriculum is not flexible to be replaced every time.

On the other hand, many learning 
providers provide the latest materials in line with market needs that can be accessed online. One of them is MOOC (Massive Open Online Course). MOOC is an online learning material with massive participant participation and is accessed online. Some early MOOC providers such as Coursera, Udacity, and edX had features such as; massive participation, openness, online access, learning material in the video material format, quizzes, exams, and discussion format (Daradoumis, Bassi, Xhafa, \& Caballe, 2013).

Learning material available at MOOC providers generally displays video material formats. Some studies reveal that MOOC learning videos are generally relatively short (five to 20 minutes). The quality of instructional videos can vary. Learning videos with minimal quality displays the teacher profile recorded with a medium shot display and combined with text and graphic presentations. For higher quality, learning videos are produced in specialized studios with complete equipment. However, there are also learning videos with low quality by directly recording teachers when teaching (Johnston, 2015).

A study at the Universitas Teknologi Indonesia found that students and lecturers cannot take advantage of online learning facilities. This research finds that there are obstacles in operating online learning properly (Divayana, 2017). Other research on the postgraduate programs of Universitas Terbuka deals with analyzing interactions between learning readiness and learning satisfaction. Self-efficacy, self-regulation, and connectedness simultaneously affect learning satisfaction (Suciati, 2017). The previous studies show that the individuality factor is the characteristics of online learning. A student is in an independent situation when dealing with a digital screen system to conduct learning activities. In this situation, the visual element of online learning material becomes an essential aspect.

Albó \& Hernández-Leo (2019) gives recommendations to emphasize visual representations of learning material and investigate how to connect learning outcomes with visual representations. Graphic elements are an essential part of the visual representation of the learning material. However, many have not paid attention to the communication function of the graphic elements. A study in the learning management system (LMS) and open course wares of Indonesian universities found that many course materials use decorative visual functions. The decorative function does not help students construct knowledge but increase their cognitive load memory (Adriyanto, Santosa, \& Syarief, 2020).

On the other hand, students who receive learning are generally digital generations accustomed to using digital devices and the internet. This reality is in line with a survey that found that the average generation born after 2000 spends more than five hours a day on online activities. Unfortunately, the literacy level in book reading is still inadequate (Adriyanto, Santosa, \& Syarief, 2019).

Berliyanto \& Santoso (2018) conducted observations at local MOOC providers in Indonesia, specifically IndonesiaX, MOOC Open University, Ciputra University Entrepreneurship Online, and FOCUS Fisipol Gadjah Mada University. IndonesiaX has the largest number and variety of courses compared to other MOOCs observed. One of this study's recommendations that strategic planning is required in implementing the MOOC. However, Kurniasari, Jusuf, \& Gunardi (2018) states that the number of courses offered by MOOC providers, including IndonesiaX, is not as many as the number of well-known international MOOC courses such as Coursera, edX, or Future Learn. This research also found that there is a low rate of completion and achievement of the IndonesiaX course. Lubis, Idrus, \& Rashid (2020) show that the total number of IndonesiaX users of 155,000 is still inadequate compared to Indonesia's total internet users of 171 million people.

Several studies have been conducted on IndonesiaX. However, not many have analyzed it from the visual aspect of learning materials. This research aims to observe and analyze IndonesiaX learning materials from the design and multimedia aspects. The study results are expected to provide recommendations for a learning material that is more attractive and comfortable for students.

\section{METHODS}

\section{Strategy of Inquiry}

The paradigm used in this research is pragmatism. It is a concern with real-world 
practice-oriented and solutions to problems. The research used a quantitative strategy with data collection methods by visual observation of material courses.

\section{Data Collections}

Visual observation is conducted using case studies on IndonesiaX learning materials (https://www.indonesiax.co.id) by comparing edX (https://www.edx.org), Coursera (https:// www.coursera.org) and Udemy (https://www. udemy.com) materials (see Figure 1). The topics presented in the MOOC are topics related to the implementation of information technology, such as digital marketing topics and user experience topics.

\section{Research Instrument}

The design principle will analyze user interface criteria and multimedia learning principles to analyze video content criteria and learning tools (see Figure 2). The design principles are categorized according to the way they work on a design. The categories used in this research are principles of implementation that help people learn from the design and principles of enhancing a design's usability. These principles are accessibility, chunking, forgiveness, legibility, performance load, 80/20 rule, consistency, control, and iconic representation (Lidwell, Holden, \& Butler, 2010).

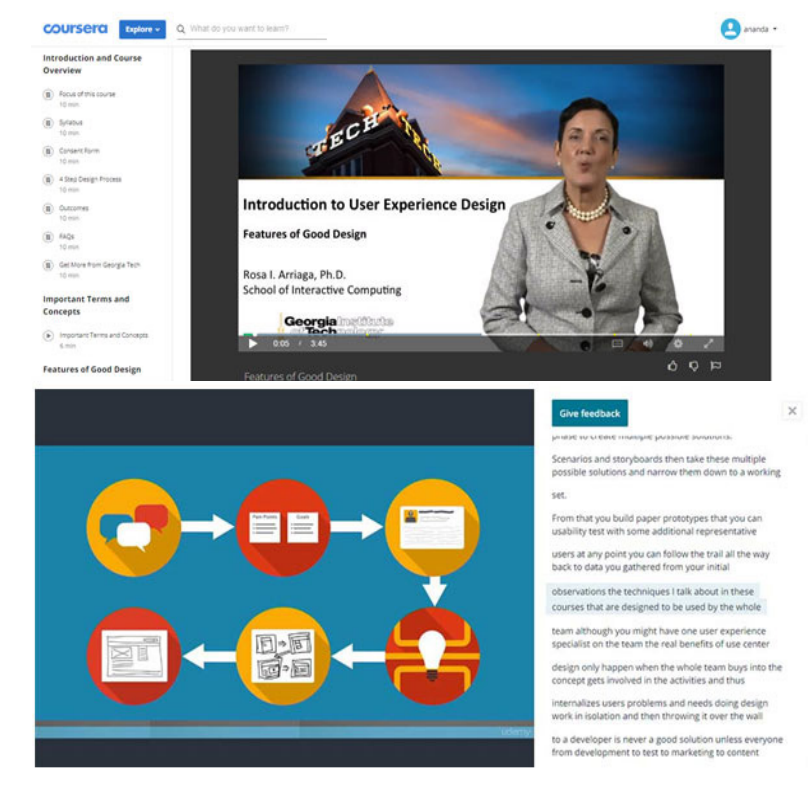

9)

(9)

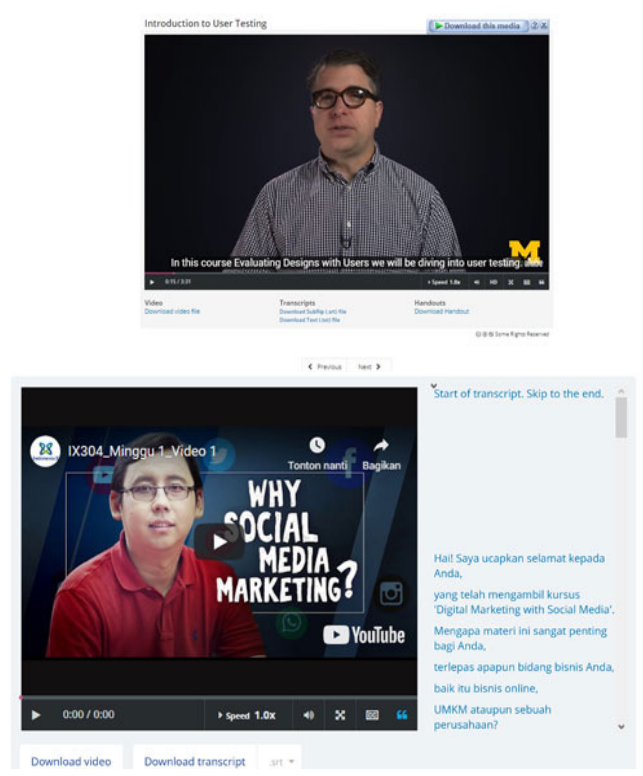

Figure 1. Coursera, edX, Udemy and IndonesiaX

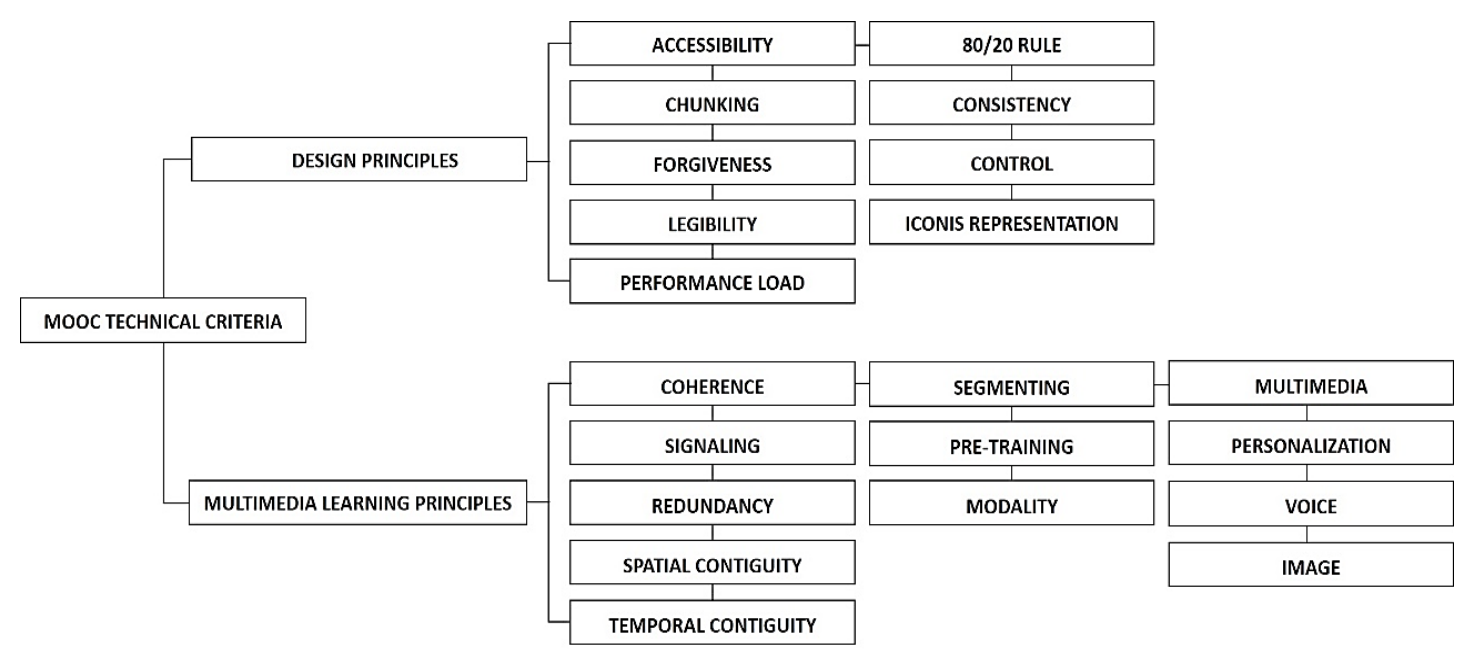

Figure 2. Design Principle and Multimedia Learning Principles 
The cognitive theory of multimedia learning (Mayer, 2009) is divided into three principles: principles for reducing extraneous processing, managing essential processing, and fostering generative processing. The first principle contains coherence, signalling, redundancy, spatial contiguity, and temporal contiguity. Later, the second principle includes segmenting, pre-training, and modality principles. Moreover, the third principle consists of multimedia, personalization, voice, and image principles.

Codes and assessment parameters are made to facilitate the evaluation. The design principle is divided into two main parts consisting of five parameters related to the principle of implementation that helps people to learn from design (accessibility, chunking, forgiveness, legibility, and performance load) and four parameters related to the principle of enhancing the usability of a design (80/20 rule, consistency, control, and iconic representation)

The principle of multimedia is divided into three parts; reducing extraneous processing principles (coherence, signalling, redundancy, spatial contiguity, and temporal contiguity), managing essential processing principles (segmenting, pre-training principle, and modality), and fostering generative processing principles (multimedia, personalization, voice, and image).

\section{Data Analysis}

A MOOC content material will be evaluated by taking part in online learning. If the content meets the parameters, then given a value of 1 . If partially fulfilled, it will be given a value of .5 , and if it does not meet, it will be given a value of 0 (Atmaja \& Firman, 2015). The parameter values are obtained from the number of parameters that meet divided by the total number of parameters for each criterion, multiplied by 5 . Multiplication by 5 is related to the range of parameter values in Table 6 . The following calculation is to get the parameter values:

Parameter value $=\frac{\text { Number of parameters fulfilled }}{\text { Total number of parameters for each criterion }} \times 5$

The scale value definition is modified from the web usability measurement, which uses a 0 to 4 scale to illustrate the presence or absence of usability problems in the observed web (Nielsen $\&$ Mack, 1994). The parameter values obtained in the calculation will get a description according to the range of values described in Table 1.

Table 1. Range of Value Parameters

\begin{tabular}{ll}
\hline $\begin{array}{l}\text { Range of Value Parameters } \\
(\boldsymbol{n})\end{array}$ & Grade \\
\hline$n>4.5$ & Excellent \\
$3.5<n \leq 4.5$ & Good \\
$2.5<n \leq 3.5$ & Fair \\
$1.5<n \leq 2.5$ & Poor \\
$0<n \leq 1.5$ & Very poor \\
$n=0$ & Not available \\
\hline
\end{tabular}

\section{RESULTS AND DISCUSSION \\ Results}

The research object is the IndonesiaX lecture material related to information technology with the topic "Digital Marketing" delivered by Juanda Ravelim. As a comparison material, the research using Udemy, Coursera, and edX material with the related information technology topic "User Experience."

\section{Layout Interface}

Navigation of the learning material using the sidebar navigation located on the left (point 1, Figure 3). The material arrangement is made using division per week. Each week there are sub materials that can be opened by dropping down every weekend. The material's main content is a learning video by presenting the lecturer (point 3, Figure 3). In addition to the learning video, there is a narrative text of the learning video (point 4, Figure 3). At the top of the learning video, a graphic shows students' progress in the following material (point 2, Figure 3).

When analyzed from the layout aspect, users are given the convenience to access the information needed. Users are given two alternative ways to enter the next sub material, first, by accessing the forward arrow button at the bottom of the learning video (point 5, Figure 3 ) and second from independently accessing the navigation menu on the left.

\section{Multimedia Elements}

The typeface for the text elements in IndonesiaX uses the sans-serif. The text element is not used as learning material on its web page 


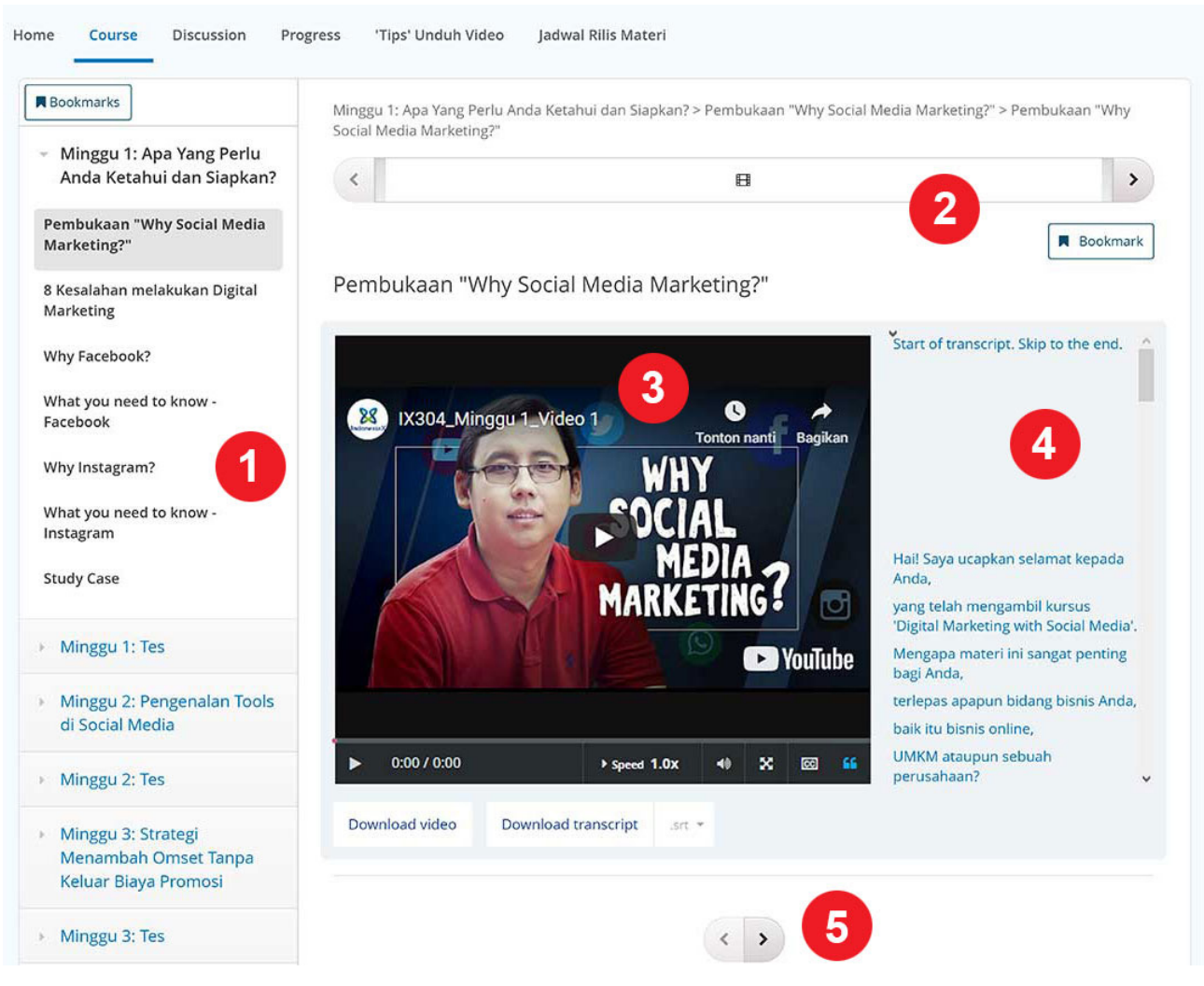

Figure 3. The Interface of IndonesiaX's Material Content

but is a part of the learning video component. The text also becomes a transcript located next to the learning video (point 4, Figure 3) that users can use to search in detail for the teacher's words about a particular topic. Coursera and Udemy further highlight text as they do with IndonesiaX. While edX still uses text as learning material in addition to learning videos. The image elements are not explicitly placed in the learning material. Images become part of the motion graphics that are in the learning video material.

The video-audio material is a significant part of IndonesiaX learning materials. Video content contains a combination of motion graphic content and the teacher's verbal narration that provides relevant information. The average video duration ranges from nine to 12 minutes. The display on the learning video shows more of the instructor profiles with the medium shot technique than the other elements. The teacher profile appears with an average of $50 \%$ to $70 \%$ of the total video duration. The video's remaining duration is filled with display images, text, motion graphics, and animation.

\section{Design Principles}

Design principles with the implementation that help people to learn from design consist of five parameters with an explanation chart that contains a description of the principles, codes, and parameters to facilitate evaluation in Table 2. The design principle is used to see the MOOC user interface being observed. Overall the value of applying principles that help users to learn from design is excellent grades, except for edX, which gets good grades, as shown in Table 3.

In terms of accessibility (DL 1), IndonesiaX has fulfilled this principle. Users can easily find which menu they want, which course is being done. The navigation display on the left makes it easy to access the desired section. The same thing applies to Udemy and Coursera. On edX there is a slight difference; the anatomical navigation menu is located at the top. There is no direct statement about the course material in writing. It displays the icon form that represents the course material, making it difficult for users to navigate it quickly because it does not display the learning material text. This situation is shown in Figure 4. 
Table 2. The Principle of Implementation That Help People to Learn from Design

\begin{tabular}{|c|c|c|}
\hline Code & Parameter & The Rule \\
\hline DL 1 & $\begin{array}{l}\text { Accessibility: this principle is needed in a design system } \\
\text { to be easily used by various user characteristics, without } \\
\text { any particular adaptations and modifications. }\end{array}$ & $\begin{array}{l}\text { Do users quickly } \\
\text { access parts of the } \\
\text { learning material? }\end{array}$ \\
\hline DL 2 & $\begin{array}{l}\text { Chunking: This method is implemented in designs with } \\
\text { complex information by dividing the information into } \\
\text { several locations. }\end{array}$ & $\begin{array}{l}\text { Does the MOOC } \\
\text { system share content } \\
\text { and information? }\end{array}$ \\
\hline DL 3 & $\begin{array}{l}\text { Forgiveness: A system can minimize deficiencies or } \\
\text { errors for its users. }\end{array}$ & $\begin{array}{l}\text { Can the system } \\
\text { anticipate if the user } \\
\text { executes incorrectly? }\end{array}$ \\
\hline DL 4 & $\begin{array}{l}\text { Legibility: Regarding the level of clarity and legibility } \\
\text { of the information presented. }\end{array}$ & Clear \\
\hline DL 5 & $\begin{array}{l}\text { Performance load: consists of cognitive load and } \\
\text { kinematic load. Cognitive load is associated with a load } \\
\text { of cognitive function activities, such as users required } \\
\text { to recall using a system. The kinematic load is related to } \\
\text { physical effort or steps in completing an activity. }\end{array}$ & $\begin{array}{l}\text { See cognitive and } \\
\text { kinematic loads in the } \\
\text { process of a system in } \\
\text { MOOC. }\end{array}$ \\
\hline
\end{tabular}

Table 3. Evaluation of Implementation That Helps People to Learn from Design

\begin{tabular}{lccccc}
\hline Parameter & \multicolumn{5}{c}{ Values } \\
\cline { 2 - 6 } Assessment & IndonesiaX & Udemy & Coursera & edX & Mean \\
\hline DL 1 & 1 & 1 & 1 & .5 & .875 \\
DL 2 & 1 & 1 & 1 & 1 & 1 \\
DL 3 & 1 & 1 & 1 & 1 & 1 \\
DL 4 & 1 & 1 & 1 & 1 & 1 \\
DL 5 & 1 & 1 & 1 & .5 & .875 \\
Parameter fulfilled & 5 & 5 & 5 & 4 & 4.750 \\
Parameter value & 5 & 5 & 5 & 4 & 4.750 \\
Grade & Excellent & Excellent & Excellent & Good & Excellent \\
\hline
\end{tabular}

Note: $1=$ parameter fulfilled; $.5=$ parameter partially fulfilled; $0=$ not available
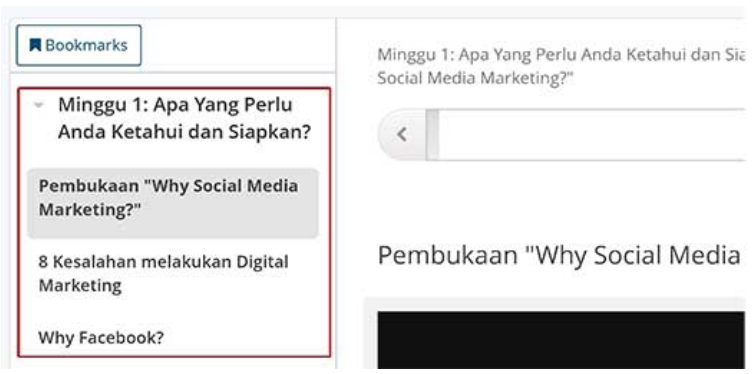

Figure 4. Drop-Down Menu on IndonesiaX (left), Icon Menu on edX (Right)

For the chunking principle (DL 2), IndonesiaX has implemented it well. One of them is by using the drop-down concept (Figure 4) to make it easier for users to see a complicated thing simpler. The explicit sharing of menu information and material content makes it easy for users to explore this system. This principle is also well applied to Udemy, Coursera, and edX.
In the forgiveness principle (DL 3), the MOOC system generally has met. The MOOC system can minimize deficiencies or errors for its users. The principle relates to accessibility and legibility principles. With the ease and clarity of information in the system, users' mistakes can be minimized. 
The legibility principle (DL 4) is related to the clarity and legibility of the information. IndonesiaX LMS is fulfilling this principle. The smallest font size of 14 pixels is quite legible by users. The different font sizes and colors for titles and sub-headings also make it easier for users to understand the information and shown in Figure 5. The same is also well applied by Udemy, Coursera, and edX.

On the performance load principle (DL 5), IndonesiaX has been well implemented. Users' ease of recalling a system and the short steps taken in executing can ease the user's cognitive load and kinematic load. This principle is related to the chunking principle. Information is broken down into sections that can make it easier for users to reduce the performance load. However, for edX, this is not fulfilled because the navigation menu requires several steps to execute a section. Design principles with enhancing the usability of design consist of four parameters with an explanation chart that contains a description of the principles, codes, and parameters to facilitate evaluation in Table 4.

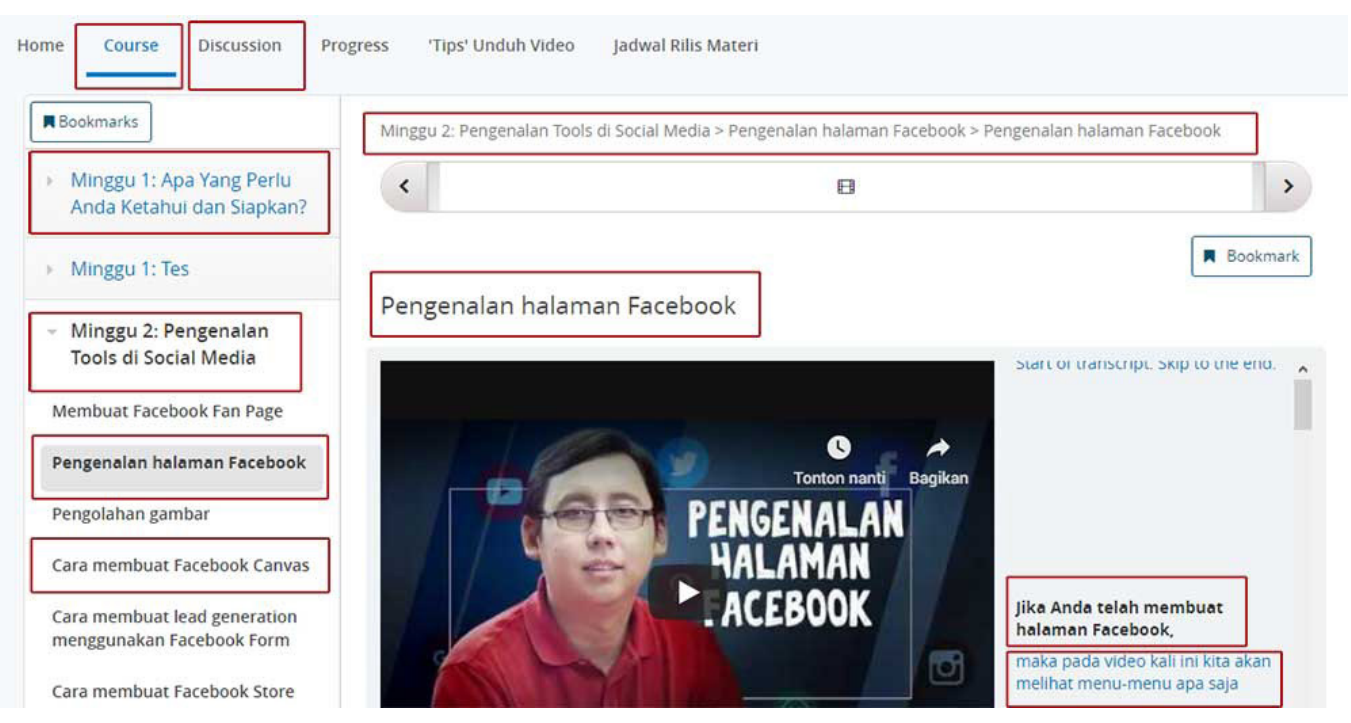

Figure 5. Typeface of Different Sizes, Thicknesses, and Colors

Table 4. The Principles of Enhancing the Usability of a Design

\begin{tabular}{|c|c|c|}
\hline Code & Parameter & The Rule \\
\hline DUS 1 & $\begin{array}{l}80 / 20 \text { rule: The functional division of a system consisting of } 80 \% \text { and } \\
20 \% \text {, the } 20 \% \text { part of the system, significantly impacts the system's } \\
80 \% \text { part. }\end{array}$ & Clear \\
\hline DUS 2 & $\begin{array}{l}\text { Consistency: this principle is beneficial for a system that is easily } \\
\text { recognized and understood by users or the target market. There are } \\
\text { four types of consistency: } \\
\text { a. Aesthetic: consistency in appearance and style (visual system); } \\
\text { b. Functional: consistency in the meaning and action of a function; } \\
\text { c. Internal: consistency of one element with other elements in the } \\
\text { system; } \\
\text { d. External: consistency of one element with other elements in a system } \\
\text { in the environment. }\end{array}$ & Clear \\
\hline DUS 3 & $\begin{array}{l}\text { Control: There is a control system that gives users the choice of usage } \\
\text { based on their needs. }\end{array}$ & Clear \\
\hline DUS 4 & $\begin{array}{l}\text { Iconic representation: Consists of similar, example, symbolic, and } \\
\text { arbitrary. Iconic representation helps make it easy for users to run a } \\
\text { system that is presented in visual form }\end{array}$ & Clear \\
\hline
\end{tabular}


The $80 / 20$ rule explains that 80 percent of a system is caused by 20 percent of its components. In connection with this principle, observations on IndonesiaX LMS will see whether 20 percent of the system's variables affect 80 percent of the overall system. Overall, for IndonesiaX's interface, this principle has been well implemented, shown in Table 5. Based on the $80 / 20$ rule principle (DUS 1 ), IndonesiaX has implemented a $20 \%$ division of functions that significantly impact the other $80 \%$. This condition can be seen in the application for navigation to learning materials that are a small part of the system but significantly impact the other $80 \%$. Udemy, Coursera, and edX well implement this principle.

The principle of consistency (DUS 2) in IndonesiaX is partially fulfilled. There are inconsistencies in aesthetics and function. Aesthetic inconsistencies can be seen in the mismatch between the layout interface and the learning video interface. The navigation menu on the IndonesiaX learning video is not consistent with the layout of the system. The learning video material seems to be an independent part of the system. Compared with Udemy, the learning video interface's consistency is similar to harmony with the system layout. Even in color to show the video timeline have similar color with Udemy's identity color (see Figure 6). The functional inconsistencies in IndonesiaX are seen in the drop-down arrow for the learning material menu on the left bar side. The use of the arrow only functions to open sub-menus, but not to close them again. EdX is also partly fulfilled by the consistency principle, while Udemy and Coursera have fulfilled the principle.

The control principle (DUS 3) is a principle that gives users the freedom to control the system according to their needs. All MOOC providers have fulfilled this principle; users are given other display alternatives to follow the material course. The iconic representation principle (DUS 4) on all MOOC providers is still partially fulfilled. The implementation of icons that use the similarity, examples, symbols, or free shapes concept has been used in some parts of the MOOC system's layout. However, there are still limitations for certain things. Some of the icons using forms that are not familiar to users have added some text explanation. There are two types of icons in this MOOC provider. A text description accompanies the first icon. The second icon, without any description, until the user hovers the cursor towards the icon, then appears (see Figure 7).

Table 5. Evaluation of Enhancing the Usability of a Design

\begin{tabular}{lccccc}
\hline Parameter & \multicolumn{5}{c}{ Values } \\
\cline { 2 - 6 } Assessment & IndonesiaX & Udemy & Coursera & edX & Mean \\
\hline DUS 1 & 1.000 & 1.000 & 1.000 & 1.000 & 1.000 \\
DUS 2 & .500 & 1.000 & 1.000 & .500 & .750 \\
DUS 3 & 1.000 & 1.000 & 1.000 & 1.000 & 1.000 \\
DUS 4 & .500 & .500 & .500 & .500 & .500 \\
Parameter fulfilled & 3.000 & 3.500 & 3.500 & 3.000 & 3.250 \\
Parameter value & 3.750 & 4.375 & 4.375 & 3.750 & 4.062 \\
Grade & Good & Good & Good & Good & Good \\
\hline
\end{tabular}

Note: $1=$ parameter fulfilled; $.5=$ parameter partially fulfilled; $0=$ not available

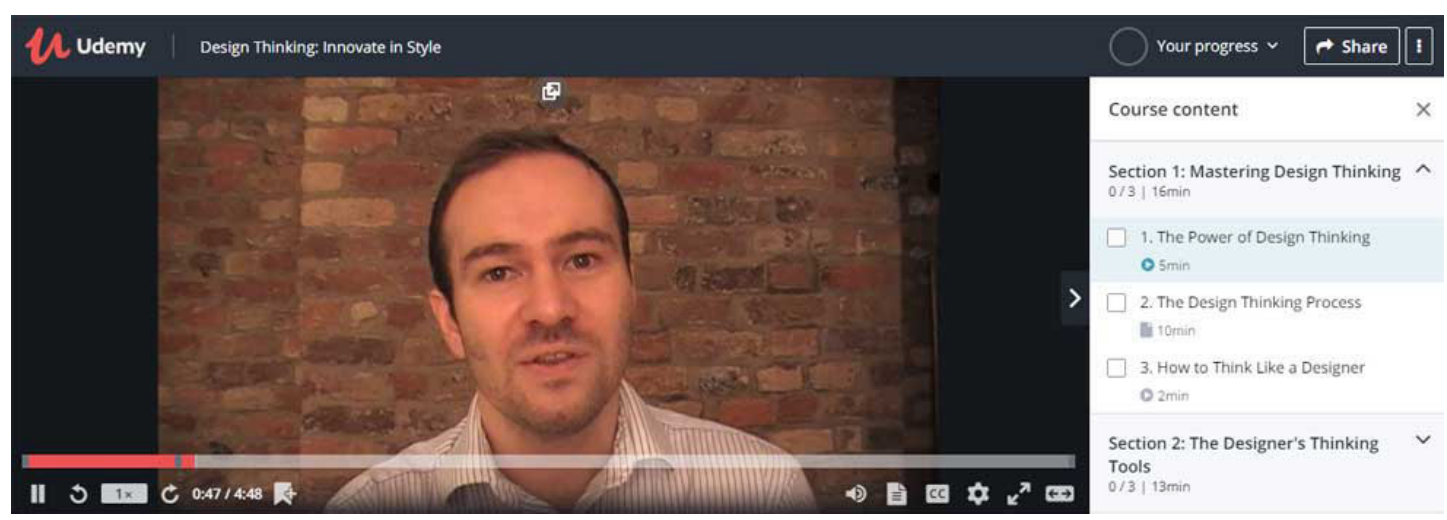

Figure 6. Interface Consistency on Udemy 


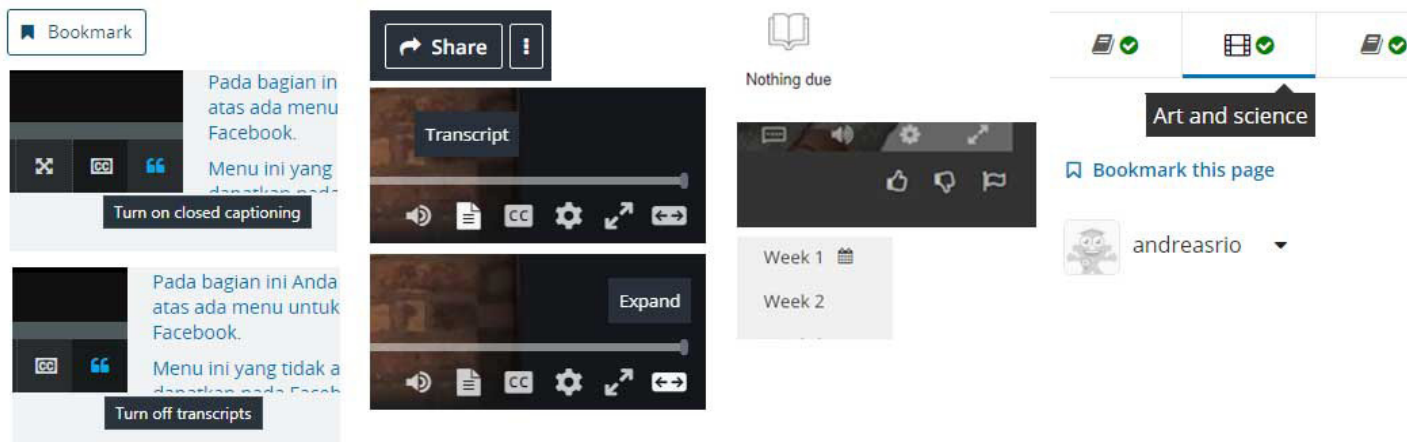

Figure 7. Icon representation on IndonesiaX, Udemy, Coursera dan edX

(Source: indonesiax.co.id, , udemy.com, coursera.org, and edx.org)

\section{Multimedia Learning Principles}

The principle of multimedia learning is used to observe the content of learning materials on MOOC providers. The principle of reducing extraneous processing consists of five parameters with an explanation chart that contains a description of the principles, codes, and parameters to facilitate evaluation in Table 6.

In general, the IndonesiaX MOOC learning material observed has a good grade for the principle of reducing extraneous processing (see Table 7).

Table 6. The Principle of Reducing Extraneous Processing

\begin{tabular}{lll}
\hline Code & Parameter & The Rule \\
\hline MLREP 1 & $\begin{array}{l}\text { Coherence principle: students learn better } \\
\text { when extraneous material is excluded rather } \\
\text { than included. }\end{array}$ & $\begin{array}{l}\text { Seeing the presence or absence of } \\
\text { irrelevant material (text, images, } \\
\text { sound). If there is an absence, it } \\
\text { has fulfilled this principle } \\
\text { Clear }\end{array}$ \\
MLREP 2 & $\begin{array}{l}\text { Signaling principle: students will learn better } \\
\text { if the learning material's essential things are } \\
\text { given a specific highlight. } \\
\text { Redundancy principle: students will learn } \\
\text { better from graphics and narration than } \\
\text { graphics, narration, and printed text. }\end{array}$ & Clear \\
MLREP 4 & $\begin{array}{l}\text { Spatial contiguity principle: Students learn } \\
\text { better when corresponding words and pictures } \\
\text { are presented near rather than far from each } \\
\text { other on the page or screen. } \\
\text { Temporal contiguity principle: Students learn } \\
\text { better when corresponding words and pictures } \\
\text { are presented simultaneously rather than } \\
\text { successively. }\end{array}$ & Clear \\
MLREP & \\
\hline
\end{tabular}

Table 7. Evaluation of Reducing Extraneous Processing

\begin{tabular}{lccccc}
\hline \multirow{2}{*}{ Parameter Assessment } & \multicolumn{5}{c}{ Values } \\
\cline { 2 - 6 } & IndonesiaX & Udemy & Coursera & edX & Mean \\
\hline MLREP 1 & .50 & 1.00 & .50 & 1.00 & .750 \\
MLREP 2 & 1.00 & 1.00 & .50 & 1.00 & .875 \\
MLREP 3 & .50 & .50 & .50 & .50 & .625 \\
MLREP 4 & 1.00 & 1.00 & 1.00 & 1.00 & 1.000 \\
MLREP 5 & 1.00 & 1.00 & 1.00 & 1.00 & 1.000 \\
Parameter fulfilled & 4.00 & 5.00 & 3.50 & 4.50 & 4.250 \\
Parameter value & 4.00 & 5.00 & 3.50 & 4.50 & 4.250 \\
Grade & Good & Excellent & Fair & Good & Good \\
\hline
\end{tabular}

Note: $1=$ parameter fulfilled; $.5=$ parameter partially fulfilled; $0=$ not available 
The coherence principle (MLREP 1) relating to text, image, and sound material that is not relevant to learning material is excluded from the material. This principle is related to the user's cognitive load when viewing learning videos. In IndonesiaX's learning video, the background displayed full ornaments that gave users a extra cognitive load to focus on the teacher. The motion graphics that appear between the video parts have not been arranged for knowledge construction (Figure 8). Sound effects, text, and images that are not a significant part of constructing knowledge are often shown in learning videos. The same thing happened in the Coursera learning video, while the Udemy and edX learning videos were already concerned with this principle.

The signaling principle (MLREP 2) has been fulfilled in the IndonesiaX learning video. Although they have not implemented good design principles such as the choice of font, size, color, shape, contrast, and composition, the essential parts are highlighted. Other MOOC providers have fulfilled this principle. Only Coursera partly fulfills the principles. In several Coursera learning videos, there is no difference in color in the text. The condition will be an essential part of the material explanation, so there is no highlighting of a particular concept.

The redundancy principle (MLREP 3) relates to the addition of written text in learning material that has been done with voice narration. In the IndonesiaX learning video, a written script is raised by following what the instructor said. This situation might aim to make it easier for users to choose which parts of the material to study further. The same is true for additional scripts that can be displayed at the bottom of the learning video. Although both of these functions can be deactivated, it can add to the user's cognitive load in focusing their attention on the teaching video if this is activated. Learning videos on Coursera, Udemy, and edX also have the same function as IndonesiaX learning videos.

IndonesiaX and other MOOC providers have fulfilled the spatial contiguity principle (MLREP 4) and temporal contiguity principle (MLREP 5). Images and text in learning materials are generally displayed close together and displayed in simultaneous time.

The principle of managing essential processing consists of three parameters with an explanation chart that contains a description of the principles, codes, and parameters to facilitate evaluation in Table 8.

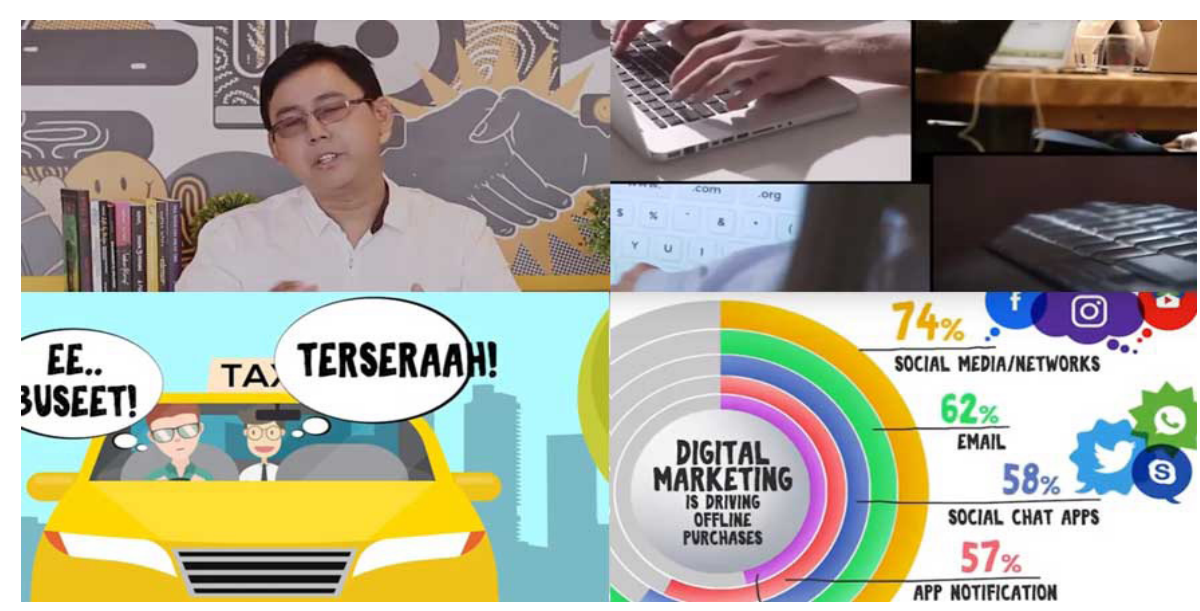

Figure 8. Higher Cognitive Load by Adding Irrelevant Material

(Source: indonesiax.co.id)

Table 8. The Principle of Managing Essential Processing

\begin{tabular}{lll}
\hline Code & Parameter & The Rule \\
\hline MLMEP 1 & $\begin{array}{l}\text { Segmenting principle: students will learn better with material } \\
\text { controlled by students, rather than linearly. }\end{array}$ & Clear \\
MLMEP 2 & $\begin{array}{l}\text { Pre-training principle: students will learn better if they understand } \\
\text { the name and characteristics of the main concept. } \\
\text { Modality principle: students will learn better with pictures and } \\
\text { spoken words compared to pictures and printed words. }\end{array}$ & Clear \\
MLMEP 3 & Clear \\
\hline
\end{tabular}


This principle relates to the process of managing information and processing material that is important by users. In general, IndonesiaX's learning material is a good grade. For the segmenting principle (MLMEP 1), the IndonesiaX material and all MOOC providers have fulfilled the principle (Table 9). The user can control the course material, delaying the course, repeating, and moving material. The use of navigation for teaching materials and navigation in teaching videos make it easier for students to control the material lesson. The right way of signaling is done by segmenting information in the learning video.

The pre-training principle (MLMEP 2) at IndonesiaX and all MOOC providers have fulfilled the principle. Management of learning material introduces the basic concepts of learning materials and understands the global concepts and links to sub-topics to be taught. This situation will make it easier for students to understand the names and characteristics of the main concepts. However, the modality principle (MLMEP 3) was only partially fulfilled by IndonesiaX. There are many learning video material in IndonesiaX that combines images with written text compared to images with spoken narration. The same thing is also found in Coursera and edX learning videos, while Udemy learning videos have fulfilled this principle by using pictures and spoken narration.

The principle of fostering generative processing consists of four parameters with an explanation chart that contains a description of the principles, codes, and parameters to facilitate evaluation in Table 10. This principle is related to the principle that fostering generative processing. Cognitive processes require deep understanding related to student motivation. They are processing this generative load related to how students can organize and integrate material learning elements. Overall, IndonesiaX's learning video material scores good grades for this principle and is above the average value of all MOOCs observed (Table 11). Implementing multimedia principles (MLFGP 1) of IndonesiaX learning videos has fulfilled the principles in detail. This condition is also the same as other MOOC providers. The material contained in the learning video is a combination of text and images and nothing that consists of only text elements.

Table 9. Evaluation of Managing Essential Processing

\begin{tabular}{lccccc}
\hline \multirow{2}{*}{ Parameter Assessment } & \multicolumn{5}{c}{ Values } \\
\cline { 2 - 6 } & IndonesiaX & Udemy & Coursera & edX & Mean \\
\hline MLMEP 1 & 1.00 & 1.00 & 1.00 & 1.00 & 1.000 \\
MLMEP 2 & 1.00 & 1.00 & 1.00 & 1.00 & 1.000 \\
MLMEP 3 & .50 & 1.00 & .50 & .50 & .625 \\
Parameter fulfilled & 2.50 & 3.00 & 2.50 & 2.50 & 2.625 \\
Parameter value & 4.17 & 5.00 & 4.17 & 4.17 & 4.375 \\
Grade & Good & Excellent & Good & Good & Good \\
\hline
\end{tabular}

Note: $1=$ parameter fulfilled, $.5=$ parameter partially fulfilled, $0=$ not available

Table 10. The Principle of Fostering Generative Processing

\begin{tabular}{lll}
\hline Code & Parameter & The Rule \\
\hline MLFGP 1 & $\begin{array}{l}\text { Multimedia principle: students will learn better from material that } \\
\text { contains a combination of text and images than text alone. }\end{array}$ & Clear \\
MLFGP 2 & $\begin{array}{l}\text { Personalization principle: students will learn better when words are } \\
\text { applied in a conversational style rather than formally. }\end{array}$ & Clear \\
MLFGP 3 & $\begin{array}{l}\text { Voice principle: students will learn better with narratives given } \\
\text { through human voices than machines' sounds. }\end{array}$ & Clear \\
MLFGP 4 $\begin{array}{l}\text { Image principle: students will not learn better with multimedia } \\
\text { material when the narrator's figure appears on the screen. }\end{array}$ & Clear \\
\hline
\end{tabular}

Table 11. Evaluation of Fostering Generative Processing

\begin{tabular}{lccccc}
\hline Parameter Assessment & \multicolumn{5}{c}{ Values } \\
\cline { 2 - 6 } & IndonesiaX & Udemy & Coursera & edX & Mean \\
\hline MLFGP 1 & 1.00 & 1.00 & 1.00 & 1.00 & 1.000 \\
MLFGP 2 & 1.00 & 0 & 0 & 0 & .250 \\
MLFGP 3 & 1.00 & 1.00 & 1.00 & 1.00 & 1.000 \\
MLFGP 4 & 0 & 1.00 & 0 & 0 & .250 \\
Parameter fulfilled & 3.00 & 3.00 & 2.00 & 2.00 & 2.500 \\
Parameter value & 3.75 & 3.75 & 2.50 & 2.50 & 3.125 \\
Grade & Good & Good & Fair & Fair & Fair \\
\hline
\end{tabular}

Note: $1=$ parameter fulfilled; $.5=$ parameter partially fulfilled; $0=$ not available 
For the personalization principle (MLFGP 2), IndonesiaX's teachers use the informal language readily accepted by ordinary users. Bringing teachers in a relaxed way by wearing casual apparel can increase the personalization of learning videos. This situation contrasts with teachers at other MOOC providers who use more formal language and wearing formal apparel. For the voice principle (MLFGP 3), all MOOC providers use human voices spoken directly by the instructor and nothing that uses voices processed from an audio software.

For the image principle (MLFGP 4), almost all MOOC providers, including IndonesiaX use narrators, and only Udemy appears without narrators at all. According to this principle, students will not learn better when the narrator's figure appears on the screen. This principle might be investigated further because MOOC providers generally use the narrator figure in the video display. Based on the image principle suggested that the instructor's appearance in multimedia material does not promote learning. This condition is because additional loads cover the potential benefits of social presence or personalization due to cognitive processing.

\section{Discussion}

This section will discuss the results that have been obtained by analyzing sections consisting of interface layouts, multimedia elements, design principles, and multimedia learning principles.

\section{Layout Interface}

Thorngate \& Hoden (2017) conducted research that showed that navigation on the left has a higher usability level than navigation at the top. Similar to navigation on IndonesiaX, the left side navigation layout model is also applied to Coursera. However, something different is found in edX, which implements top navigation and Udemy on the right. Research conducted by Bowen, Ellis \& Chaparro (2017) compared long navigation, which contains a lot of submenu content, and short navigation. Experiments have found that long navigation is more usable for the user. These findings can support navigation in online learning because learning materials can contain a lot of material topics. Users can more easily explore with a complete menu rather than displaying a portion of the menu as on the edX.

\section{Multimedia Elements}

Research conducted on edX's learning videos found that short video duration will increase student engagement compared to longduration videos (Guo, Kim \& Rubin, 2014). A right segmentation setting in video production can be done by setting the video duration to no more than six minutes. Further, the study mentioned that informal teaching styles that emphasize personal feelings enhance student engagement (Guo et al., 2014). Learning video on IndonesiaX is still of a sufficiently long duration compared to what is suggested by this study. However, the informal teaching style was conducted by following the recommendations of the study.

\section{Design Principles}

The segmentation applied to the IndonesiaX system makes it easy for users to see certain parts grouped separately. The use of the principle of chunking (DL 2) is in line with several studies on using the principle of chunking. The principle aims to reduce students' cognitive load by dividing pieces of information into small units. Belcher (2018) experimented on the implementation of chunking to paragraph settings in online learning content. Although there is no significant difference, this research considers other things that can affect the learning process, such as timing structure and active engagement.

Morrison-Jones \& North (2019) researched to see the effects of typography in LMS. Four typographic elements are examined, namely the typeface, size, alignment, and emphasis. The results of these four elements have a significant effect on knowledge sharing effectiveness. Arial or sans-serif typeface is the preferred typeface, and 12 points are the letter's preferred size. Left and justified alignment is the preferred alignment. Sentence case emphasis is the preferred type of emphasis. IndonesiaX has implemented this legibility (DL 4) principle well.

The consistency principle (DUS 2) is related to user comfort in seeing the system interface it faces. In IndonesiaX this is still partially fulfilled. The IndonesianX identity can be derived in the implementation of the interface. The use of color and shape identities can be applied to certain parts of the interface 
and materials so that there is harmony between the visual elements in IndonesiaX.

In general, the icon representation (DUS 4) is well implemented, although specific icons for unfamiliar users will be confusing. Using an icon that is immediately recognizable by the user will make it easier for the user to understand the information provided. Modified icons can delay the processing of information and increase the cognitive load. Icons should include text that describes the information or be provided when required by the user.

\section{Multimedia Learning Principles}

The coherence principle (MLREP 1) is about excluding the material that is not relevant to learning material. In IndonesiaX video material, there are sound effects, text, and images that are not a significant part of constructing knowledge, leading to a high cognitive load. However, there is a study that is counter to this principle. Adding approximately 50 percent of irrelevant information but interesting information on multimedia material did not give low test results. A possible explanation is that adding interesting information acts as a useful function and keeps students' attention to authentic learning (Muller, Lee, \& Sharma, 2008).

For this reason, further investigation is needed related to this principle. With in-depth experiments, it is hoped that this principle can be strengthened. According to the coherence principle, further research can also be investigated concerning the teaching room's background. Do students prefer the appearance of straight and black or white background so that the instructor's appearance can be seen and without any other distraction? Alternatively, do students prefer the instructor's appearance to be in a particular room, with the risk of having an extra element but providing a sense of comfort in learning?

The redundancy principle (MLREP 3 ) relates to the addition of written text into voice narration. In IndonesiaX this principle is still partially fulfilled. However, there is research that conflicts with the redundancy principle. The study was conducted by comparing the effects of learning videos with caption and without caption. This research is to find a relationship between motivation and student achievement. An impressive result was found that there were no differences in motivation and achievement in video with or without caption. Caption videos can be used as a motivational factor, an alternative to the linguistic element, increasing attention, and preventing misunderstanding (Culbertson, Shen, Andersen, \& Jung, 2017).

Students will learn better with pictures and spoken words in the modality principle than pictures and printed words. This condition is related to the dual-channel assumption that receives images through the visual sense and hears information through the auditory sense. According to this theory, adding text to an image will increase the cognitive load. Based on the modality principle (MLMEP 3) was only partially fulfilled by IndonesiaX. The situation is in line with research that examines the addition of images to support learning in a biology lesson in elementary schools. The picture should be added to the spoken text compared to the written text, for school children viewing images while reading can increase cognitive capacity, especially from their visual channel. Pictures enhanced learning, but the text should be spoken rather than written (Herrlinger, Höffler, Opfermann, \& Leutner, 2017).

In the image principle (MLFGP 4), students will not learn better with multimedia material when the narrator's figure appears on the screen. However, almost all MOOC providers, including IndonesiaX use narrators. However, there is research that conflicts with the image principle.

A study conducted a comparison between learning videos that use and without the instructor's facial appearance (Kizilcec, Bailenson, \& Gomez, 2015). Students who saw the instructor's face had a better learning experience than students who did not. In contrast, students who prefer learning without the instructor's facial appearance argue to avoid distraction because there is a possibility that students dislike the instructor's appearance. Based on the results of the study, a learning material is made that combines the two appearances. The result is that material with variations of these combinations is strategically better than constant display conditions; also, the learning outcome results not change. 
According to this research, IndonesiaX's video lesson has used a combination of narrator display and learning material. Further research can be done by observing which part is more dominant in the video lesson's duration, whether the narrator's appearance or learning material. Another thing that can be considered further research is determining when to present the narrator and display learning material.

\section{CONCLUSION}

In general, the implementation of design principles in IndonesiaX materials received a good grade. Although there are still lacking in details (consistency, iconic representation, coherence, redundancy, modality, and image principles), overall have good grades. Further research can be carried out to analyze the components that are still lacking. IndonesiaX is relatively new to the MOOC platform in Indonesia, so it can still be developed further. It is hoped that learning materials in IndonesiaX can be directed to increase student engagement in online learning by paying attention to visual aspect, specifically the design and multimedia learning principles.

The weakness of this research is to observe one learning material by comparing other MOOC materials. The reason for using another MOOC is to compare to the well-established MOOCs. For further research, observation of several learning materials in the same MOOC can be alternative research. Comparisons can be made using different types of learning materials. By multiplying, cases can enrich similar research. However, this research's suggestions and recommendations are expected to reduce the deficiencies that exist in general. As a support for the "Kampus Merdeka" program, the role of Indonesian MOOC is crucial. Improvement and further development are expected to improve the quality of online learning.

\section{REFERENCES}

Adriyanto, A. R., Santosa, I., \& Syarief, A. (2019). Memahami perilaku generasi $\mathrm{Z}$ sebagai dasar pengembangan materi pembelajaran daring. [Understanding generation Z's behavior as a basis for developing online learning materials]. Seni, Teknologi dan Masyarakat, 2, 165173. https://doi.org/10.33153/semhas. v2i0.116.

Adriyanto,A. R., Santosa, I., \& Syarief,A. (2020). Evaluasi heuristik sistem pengelolaan pembelajaran daring perguruan tinggi di Indonesia. [Heuristic evaluation of higher education online learning management systems in Indonesia]. ANDHARUPA: Jurnal Desain Komunikasi Visual \& Multimedia, 6(02), 215-234. https://doi. org/10.33633/andharupa.v6i02.3592.

Albó, L., \& Hernández-Leo, D. (2019). Conceptualizing a visual representation model for MOOC-based blended learning designs. Australasian Journal of Educational Technology, 36(4), 1-26. https://doi.org/10.14742/ajet.5178.

Atmaja, F. D., \& Firman, A. (2015). Perincian parameter usability tipe pengguna browser dan evaluator pada situs web e-commerce Indonesia. [Details of usability parameters for browser user and evaluator types on Indonesian e-commerce websites]. (Undergraduate Thesis, Institut Pertanian Bogor). http://repository.ipb. ac.id/handle/123456789/76039.

Belcher, T. G. (2018). The effects of randomized appearance of text chunks in nurse eLearning lessons (Doctoral Dissertation, Kansas State University). https://krex.kstate.edu/dspace/handle/2097/38658.

Berliyanto, B., \& Santoso, H. B. (2018). Indonesian perspective on massive open online courses: Opportunities and challenges. Journal of Educators Online, 15(1), 1-14. https://doi.org/10.9743/ JEO2018.15.1.11.

Bowen, A., Ellis, J., \& Chaparro. B. (2017). Long nav or short nav? Student responses to two different navigational interface designs in LibGuides version 2. The Journal of Academic Librarianship, 44(3), 391-403. https://doi.org/10.1016/j. acalib.2018.03.002.

Culbertson, G., Shen, S., Andersen, E., \& Jung, M. (2017, February). Have your cake and eat it too: Foreign language learning with a crowdsourced video captioning 
system. Paper presented at the $2017 \mathrm{ACM}$ Conference on Computer Supported Cooperative Work and Social Computing, Portland Oregon USA. https://doi. org/10.1145/2998181.2998268.

Daradoumis, T., Bassi, R., Xhafa, F., \& Caballe, S. (2013, 28-30 October). A review on massive e-learning (MOOC) design, delivery and assessment. Paper presented at the 2013 Eighth International Conference on P2P, Compiegne, France. https://doi.org/10.1109/3PGCIC.2013.37.

Divayana, D. G. H. (2017). Evaluasi pemanfaatan e-learning di Universitas Teknologi Indonesia menggunakan model CSE-UCLA. [Evaluation of the use of e-learning at the Universitas Teknologi Indonesia using the CSE-UCLA model]. Cakrawala Pendidikan, 36(2), 280-289. https://doi.org/10.21831/cp.v36i2.12853.

Guo, P. J., Kim, J., \& Rubin, R. (2014, 4-5 March). How video production affects student engagement. Paper presented at the First ACM Conference on Learning, Atlanta, Georgia, USA. https://doi. org/10.1145/2556325.2566239.

Herrlinger, S., Höffler, T. N., Opfermann, M., \& Leutner, D. (2017). When do pictures help learning from expository text? Multimedia and modality effects in primary schools. Research in Science Education, 47(3), 685-704. https://doi.org/10.1007/s11165016-9525-y.

Johnston, T. C. (2015). Lessons from MOOCS: Video lectures and peer assessment. Academy of Educational Leadership Journal, 19(2), 91-97. https://www.abacademies.org/articles/ aeljvol19no22015.pdf.

Kizilcec, R. F., Bailenson, J. N., \& Gomez, C. J. (2015). The instructor's face in video instruction: Evidence from two largescale field studies. Journal of Educational Psychology, 107(3), 724-739. https://doi. org/10.1037/edu0000013.

Kurniasari, F., Jusuf, E., \& Gunardi, A. (2018). The readiness of Indonesian toward
MOOC system. International Journal of Engineering \& Technology, 7(3), 1631-1636. https://doi.org/10.14419/ijet. v7i3.15431.

Lidwell, W., Holden, K., \& Butler, J. (2010). Universal principles of design. Singapore: Rockport Publishers.

Lubis, A. H., Idrus, S. Z. S., \& Rashid, S. A. (2020). The exposure of MOOC usage in Indonesia. International Journal of Scientific \& Technology Research, 9(2), 2716-2720. https://www.ijstr.org/finalprint/feb2020/The-Exposure-Of-MoocUsage-In-Indonesia.pdf.

Mayer, R. E. (2009). Multimedia learning ( $2^{\text {nd }}$ ed). Cambridge: Cambridge University Press.

Morrison-Jones, N., \& North, T. L. (2019). Typographic effect on learning management system effectiveness. World Journal of Educational Research, 6(2), 321-329. https://doi.org/10.22158/wjer. v6n2p321.

Muller, D. A., Lee, K. J., \& Sharma, M. D. (2008). Coherence or interest: Which is most importantin online multimedia learning? Australasian Journal of Educational Technology, 24(2), 211-221. https://doi. org/10.14742/ajet.1223.

Nielsen, J., \& Mack, R. L. (1994). Usability inspection methods. New York, NY: John Wiley \& Sons.

Suciati, S. (2017). Interaksi kesiapan belajar dan kepuasan terhadap layanan pada pembelajaran onlineprogrampascasarjana. [Interaction between learning readiness and satisfaction and the learning service in a graduate online learning program]. Cakrawala Pendidikan, 36(1), 70-80. https://doi.org/10.21831/cp.v36i1.12733.

Thorngate, S., \& Hoden, A. (2017). Exploratory usability testing of user interface options in LibGuides 2. College \& Research Libraries, 78(6), 844-861. https://doi. org/10.5860/crl.78.6.844. 